\title{
DISSERTAÇÃO
}

\section{Humanização do parto nos contextos público e privado no Distrito Federal}

Ticiana Ramos Nonato

Curso: Mestrado em Sociologia

Data da defesa: 15 de outubro de 2007

Orientadora: Prof ${ }^{\mathrm{a}}$ Dr Lourdes Maria Bandeira

Resumo

Esta dissertação objetiva compreender a inserção da humanização do parto nos contextos público e privado da assistência obstétrica, a partir de pesquisa realizada no Distrito Federal, durante o ano de 2006 e meados de 2007, tendo como locus empírico duas instituições: um hospital privado e a Casa de Parto de São Sebastião.

Para a realização da análise comparativa foram utilizados os métodos da observação nos cursos e palestras para gestantes oferecidos por estas instituições e da entrevista em profundidade com 15 mulheres, antes e depois do parto e 14 profissionais, totalizando 42 entrevistas.

A análise de conteúdo revelou profundas diferenças nas expectativas e no atendimento relatado pelas mulheres de acordo com o contexto da assistência, resultando em uma série de dificuldades para a realização da proposta de humanização do parto. As mulheres do contexto privado planejaram seu parto, mas a maioria não 
conseguiu atingir esse planejamento, por terem feito cesariana. As narrativas das mulheres do contexto público foram marcadas pela ausência (baseada na negação ou dúvida) e pela dificuldade de elaborarem criticamente sobre a forma como foram assistidas. Entre os profissionais, foi observada uma série de diferenças entre os contextos analisados, sendo as principais relativas ao caráter com o qual a proposta é percebida (individual, no contexto privado, e institucional, no contexto público) e os pontos antagônicos de referência.

Palavras-chave: humanização do parto, assistência obstétrica, gestantes, público e privado na saúde. 